\title{
PENYULUHAN DAN PELATIHAN PEMANFAATAN KELAPA SEBAGAI PRODUK JUAL UNTUK MENINGKATKAN EKONOMI MASYARAKAT DESA SAWAHAN TRIMURTI SRANDAKAN KABUPATEN BANTUL
}

\section{Counseling and Training the Use of Coconut as a Selling Product to Improve the Community Economy of Trimurti Sawahan Village, Bantul District}

\author{
Erni Suryandari Fathmaningrum*, Margaretha Dharmayanti Harmanto
}

Pogram Studi Akuntansi Universitas Muhammadiyah Yogyakarta

Jl. Brawijaya, Geblagan, Tamantirto, Kec. Kasihan, Yogyakarta, Daerah Istimewa Yogyakarta 55183

*Alamat korespondensi : erni.suryandari34@gmail.com

(Tanggal Submission: 4 November 2020, Tanggal Accepted: 28 Desember 2020)

\begin{abstract}
ABSTRAK
Desa Sawahan memiliki banyak potensi sumber daya yang dapat diolah dan dijadikan nilai Ekonomi. Permasalahan yang ada pada Masyarakat di desa Sawahan Trimurti Srandakan Bantul adalah masalah ekonomi kreatif. Rendahnya ekonomi kreatif di desa tersebut, menyebabkan pemanfaatan sumber daya alam belum dikelola secara optimal, sehingga kegiatan program pengabdian ini bertujuan khusus untuk memotivasi masyarakat tentang pentingnya inovasi untuk menumbuhkan ekonomi masyarakat dengan memanfaatkan produk kebun seperti kelapa untuk dijadikan Virgin Oil Coconut (VCO) yang bisa bernilai ekonomi. Latar belakang tersebut yang mendorong adanya kegiatan pengabdian masyarakat pelatihan pembuatan VCO dengan sasaran ibu-ibu PKK daerah Sawahan Trimurti Srandakan Bantul. Pada proses pengabdian ini yang dilakukan antara lain sosialisasi dan penjaringan peserta, presentasi materi pembuatan VCO, demonstrasi pembuatan VCO dan evaluasi kegiatan. Manfaat yang diharapkan layanan ini untuk masyarakat mendapatkan pengalaman dalam mengeksplorasi dan menumbuhkan potensi swadaya masyarakat, masyarakat mampu berinovasi dan kreatif untuk menumbuhkan ekonominya dengan mengeksploitasi potensi di lingkungannya, mengembangkan semangat kewirausahaan di masyarakat. Hasil kegiatan pengabdian ini membawa dampak signifikan dengan meningkatnya kegiatan kemasyarakatan dalam hal pemanfaatan produk kelapa menjadi produk VCO yang mempunyai nilai jual tinggi. Selain itu pelaksanaan program pengabdian ini membawa perubahan pola pikir dan cara pandang masyarakat di Desa Sawahan Trimurti Srandakan Bantul dalam pemanfaatan kelapa untuk pembuatan VCO dan pemasarannya.
\end{abstract}

Kata kunci: VCO, kewirausahaan, inovasi, kelapa, ekonomi 


\section{PENDAHULUAN}

Perguruan tinggi sebagai sumber ilmu pengetahuan, memiliki sumberdaya manusia yang handal harus mampu memberikan alternatif pemberdayaan dan solusi dalam Pemberdayaan masyarakat dusun Sawahan Trimurti Srandakan masih membutuhkan banyak dukungan dari berbagai pihak, terutama dunia pendidikan tinggi. Dimana pelaku utama dalam mendukung kegiatan pemberdayaan ini adalah dosen dan mahasiswa. Dukungan ini dimaksudkan agar potensi sumberdaya wilayah dan penduduknya dapat dimanfaatkan secara optimal berdasarkan asas manfaat untuk kepentingan bersama. Upaya pemberdayaan tersebut perlu dilakukan agar masyarakat di dusun Sawahan Srandakan mampu mengoptimalkan sumberdaya yang ada dan agar masyarakat secara keseluruhan mencapai tingkatan hidup yang lebih baik.

Perguruan tinggi sebagai sumber ilmu pengetahuan, memiliki sumberdaya manusia yang handal harus mampu memberikan alternatif pemberdayaan dan solusi dalam menghadapi berbagai permasalahan yang dihadapi oleh masyarakat dan pemerintah daerah. Hal ini sesuai dengan mandat dalam Tri Dharma Perguruan Tinggi, khususnya dharma yang ketiga "Pengabdian Kepada Masyarakat". Salah satu dharma yang dimaksud adalah, dimana dosen melakukan kegiatan pengabdian dengan secara langsung terjun di lapangan untuk mencari solusi dan menyelesaikan permasalahan yang ada di masyarakat. Pada kegiatan ini fokus utamanya adalah pemecahan masalah yang dihadapi oleh stakeholders.

Program-program dan kegiatankegiatan yang dilaksanakan sesuai dengan kebutuhan masyarakat dan stakeholders (bottom up). Kegiatan pengabdian ini dilaksanakan di Desa Sawahan Trimurti Srandakan Bantul dengan melibatkan 9 (sembilan) mahasiswa. Desa Sawahan Trimurti sendiri merupakan salah satu desa yang ada di
Kecamatan Srandakan.dengan mata pecaharian penduduknya adalah bertani, pedagang dan industry kecil dan merupakan desa yang dekat dengan pesisir laut.

Desa Sawahan memiliki banyak potensi sumber daya yang dapat diolah dan dijadikan nilai Ekonomi. Waktu tempuh yang diperlukan menuju Desa ini berkisar kurang lebih 1jam dari Kota Yogyakarta. Di desa Sawahan banyak terdapat tanaman kelapa, dimana buah kelapa hanya digunakan untuk memasak dalam bentuk santan padahal mulai dari kulit kelapa hingga batoknya bisa dimanfaatkan. Prioritas masalah kegiatan pengabdian kepada masyarakat yang dilakukan Desa Sawahan Trimurti Srandakan Bantul adalah masalah ekonomi kreatif. Hal ini dikarenakan rendahnya ekonomi kreatif di desa tersebut, pemanfaatan sumber daya alam yang belum dikelola secara optimal serta rendahnya kesadaran masyarakat akan arti pentingnya pendidikan dalam pengembangan desa yang lebih maju dan mandiri menjadikan prioritas masalah yang harus diselesaikan.

Prioritas dalam kegiatan pengabdian yang dilaksanakan berfokus pada cara memanfaatkan hasil perkebunan yang ada di Desa Sawahan secara optimal untuk meningkatkan perekonomian masyarakat dan cara mengoptimalkan kelapa yang begitu banyak di Sawahan Trimurti Srandakan menjadi Virgin Coconut Oil (VCO) dimana hal tersebut diharapkan dapat untuk meningkatkan penghasilan masyarakat.

Minyak kelapa murni yang sering dikenal dengan minyak perawan, minyak dara atau Virgin Coconut Oil (VCO) sangat bermanfaat untuk kesehatan (Alam Syah, 2005). Tren masyarakat saat ini yang kembali pada pola makanan untuk kesehatan dari alam semakin membuat VCO banyak digemari. Kegunaan dari VCO antara lain mengurangi lemak yang ada pada tubuh, menangkal radikal bebas, menurunkan kadar kolesterol, sebagai cadangan antioksidan dalam tubuh, 
menurunkan resiko terjadinya penyakit jantung dan kanker (Widiyanti, 2015). Minyak VCO murni juga banyak digunakan dalam industri farmasi, kosmetika, susu formula, maupun sebagai minyak goreng mutu tinggi. Minyak VCO murni dapat menanggulangi beragam penyakit pada manusia. Untuk pengobatan penyakit, Minyak VCO murni digunakan untuk mengobati HIV-AIDS, kanker, hepatitis, osteoporosis, diabetes, penyakit jantung, obesitas, dan berbagai penyakit yang disebabkan oleh mikroba (Ahmad, 2006).

Untuk kosmetika, Minyak VCO murni sering digunakan pada minyak telon, handbody, atau pelembap wajah. Selain itu, Minyak VCO murni juga mampu memperbaiki sistem pencernaan. Hal ini dikarenakan asam lemak rantai menengah (MCFA) yang terkandung dalam VCO langsung dapat diserap melalui dinding usus tanpa harus mengalami proses hidrolisis dan enzimatis sehingga langsung dimetabolisme dalam hati untuk diproduksi menjadi energi. VCO juga dapat digunakan untuk memasak dan menggoreng. Minyak VCO direkomendasikan dengan kuat oleh para dokter di Amerika sebagai ingredien dalam susu formula dan sapihan (Rindengan \& Novarianto, 2007)

VCO itu sendiri merupakan minyak yang dibuat dari kelapa tua yang diolah secara sederhana, pemasakan dilakukan pada suhu kurang dari 60 derajat, mempunyai karakteristik tahan terhadap panas, cahaya, oksigen dan tidak mudah tergradasi karena struktur kimianya tidak memiliki ikatan ganda (Susanto, 2013). VCO mempunyai hampir 90\% asam lemak tak jenuh dan sisanya asam lemak jenuh sehingga dapat dicerna baik oleh tubuh (Setiaji dan Prayuga, 2006). Karakteristik lain dari VCO memiliki warna yang jernih, beraroma khas, dan rasanya gurih. Banyaknya manfaat yang ada pada VCO menjadikan minyak ini menjadi peluang usaha yang dapat dijadikan solusi untuk menambah ekonomi keluarga (Raras et.al., 2016).

Peluang usaha yang terbaca ini membuat tim pengabdian dari UMY melakukan pengabdian untuk para remaja putri dan ibu-ibu rumah tangga di daerah Sawahan Trimurti Srandakan Bantul untuk membuat VCO. Adanya pengabdian masyarakat ini diharapkan membatu warga dusun Sawahan meningkatkan nilai ekonomi dari kelapa dan meningkatkan pendapatan masyarakat. Selain itu proses pembuatan yang sederhana, murah dan mudah membuat kegiatan ini dapat dilakukan skala rumah tangga. Proses pembuatan yang juga memerlukan perlatan sederhana ini membuat biaya operasional yang kecil dan keuntungan yang relatif banyak (Hidayat \& Alamsyah, 2010). Pada pengabdian masyarakat ini dilakukan pelatihan pembuatan VCO menggunakan bantuan enzim papain yang berasal dari buah pepaya (Fitriani, 2017).

Tujuan yang ingin dicapai dari kegiatan ini antara lain : (1) memberikan pengetahuan kepada masyarakat tentang pemanfaatan buah kelapa sebagai bahan baku pembuatan VCO, (2) memberikan pengarahan kepada masyarakat tentang manfaat $\mathrm{VCO}$, (3) memberikan keterampilan kepada masyarakat tentang bagaimana cara pembuatan VCO sebagai produk makanan yang sehat, (4) menghasilkan produk VCO, (5) memberikan wacana tentang pendirian usaha kecil VCO serta bagaimana manajemen pemasarnnya.

Target yang ingin dicapai dalam kegiatan ini adalah : (1) mengajak masyarakat daerah Sawahan Trimurti Srandakan Bantul untuk dapat memanfaatkan kelapa sebagai bahan baku pembuatan VCO, (2) memberikan gambaran manfaat VCO bagi kesehatan dan mengurangi ketergantungan penggunaan obatobat kimia, (3) menghasilkan inovasi diversifikasi produk olahan kelapa menjadi minyak kelapa murni (VCO) yang harapannya dapat meningkatkan pendapatan masyarakat di 
dusun Sawahan, (4) memberikan peluang usaha bagi masyarakat dan, (5) memberikan gambaran bagaimana pengelolaan usaha VCO mulai dari perencanaan, produksi, pengelolaan dan pemasaran produk. Permasalahan yang ada adalah banyaknya pohon kelapa di dusun tersebut dimana buahnya belum diolah dan dimanfaatkan secara optimal oleh masyarakat dusun Sawahan untuk meningkatkan perekonomian dan penghasilan masyarakat.

\section{METODE KEGIATAN}

Program pengabdian yang akan dilaksanakan di desa Sawahan Trimurti Srandakan bantul adalah sebagai berikut:

1. Sosialisasi dan koordinasi program pengabdian masyarakat

Kegiatan ini dilakukan untuk saling memberikan informasi dan bersama antara masyarakat dan pengabdi mengatur atau menyepakati kegiatan pengabdian yang akan dilakukan, khususnya pelatihan pembuatan VCO.

2. Penyuluhan dan seminar tentang Perekonomian

Masyarakat/Kewirausahaan

Bertujuan untuk memeberikan pemahaman pentingnya masyarakat mengetahui bahwa saat ini penting sekali untuk berwirausaha yang berguna menunjang perekonomiannya, keluarga bahkan orang lain

3. Pelatihan dan demonstrasi membuat, VCO

Bertujuan memanfaatkan kelapa berlimpah menjadi VCO yang merupakan produk olahan yang bermanfaat dan memiliki nilai jual tinggi untuk meningkatkan perekonomian masyarakat sekaligus berlatih cara mengemas yang baik serta berlatih cara memasarkan hasil produk masyarakat agar laku di pasaran.
Tahapan-tahapan yang dilakukan pada kegiatan pengabdian kepada masyarakat antara lain:

1. Tahap Persiapan dan pembekalan

Tahapan persiapan pada kegiatan pengabdian kepada masyarakat ini berupa sosialisasi dan penjaringan peserta pengabdian. Pada saat sosialisasi dilakukan dengan meminta ijin kepada aparat setempat, kemudian mengajak ibu ibu PKK Sawahan Trimurti Srandakan yang mempunyai semangat kerja dan belajar yang tinggi, tidak bekerja, dan bersedia mengikuti pelatihan dan pendampingan sampai dengan selesai. Peserta dibentuk menjadi beberapa kelompok dengan masing-masing kelompok terdiri dari 5 orang. Pembentukan kelompok bertujuan mempermudah proses transfer informasi dan komunikasi serta pembelajaran. Tujuan dari proses sosialisasi dan penjaringan peserta antara lain :

1) Memberikan informasi kepada aparat desa dan peserta pelatihan tentang tujuan dan maksud diadakan pelatihan pembuatan VCO.

2) Melakukan pendataan permasalahan yang dihadapi masyarakat dusun Sawahan Srandakan tentang pemanfaatan peningkatan nilai tambah kelapa sebagai bahan baku pembuatan VCO

3) Mendiskusikan lokasi dan jadwal pelaksanaan program kegiatan pengabdian kepada masyarakat ini.

2. Tahap Pelaksanaan

\section{Presentasi}

Tim pengabdian pada masyarakat mempersiapkan materi dan bahan peraga pembuatan VCO yang kemudian dipresentasikan kepada peserta pelatihan. Materi yang disajikan saat presentasi antara lain : 
1) Manfaat VCO sebagai produk makanan sehat

2) Pemanfaatan kelapa sebagai bahan baku pembuatan VCO

3) Tahapan proses pembuatan VCO

\section{Pelatihan dan Demonstrasi pembuatan}

Pebuatan VCO meliputi beberapa tahapan proses antara lain (Palungkun, 2001):

1) Pembuatan krim santan dari minyak kelapa

- Kelapa dikupas, diambil daging buahnya

- Daging buah kelapa diparut kemudian ditambahkan air dengan perbandingan 1:1, kemudian ditekan dan diremas setelah itu diperas sampai air habis

- Filtrat hasil perasan yang disebut dengan santan dimasukkan ke dalam toples dan ditutup rapat selama 2 jam hingga diperoleh 2 lapisan, yaitu lapisan atas yang disebut dengan krim dan lapisan bawah yang disebut dengan skim

- Lapisan dipisahkan dan diambil lapisan atasnya (krim)

2) Pembuatan $\mathrm{VCO}$ dengan enzim papain

- Krim yang sudah dipisahkan diambil $100 \mathrm{ml}$

- Tambahkan 10 gram parutan buah pepaya yang masih muda kedalam krim kemudian aduk hingga rata

- Diamkan selama kurang lebih 24 jam dalam toples tertutup

- Setelah terbentuk 3 lapisan, pisahkan minyak kemudian saring

Evaluasi Kegiatan

Evaluasi kegiatan dilaksanakan saat pelaksanaan pemberian materi dan demonstrasi, serta jumlah produk yang dihasilkan.

\section{HASIL DAN PEMBAHASAN}

Kegiatan ini dilaksanakan di Desa
Sawahan Trimurti Srandakan Bantul.
Pelaksanaan kegiatan pengabdian ini dibantu 9 orang mahasiswa Universitas Muhammadiyah Yogyakarta dan masyarakat sebagai obyek dari pengabdian ini. Kegiatan pengabdian ini mendapat respon yang luar biasa dari perangkat desa dan masyarakat. Ini bisa dibuktikan dengan setiap kegiatan/program yang dilakukan masyarakat bersedia hadir dan meluangkan waktu mereka mengikuti kegiatan ini dari sejak sosialisasi dan koordiansi, penyuluhan, sampai ke pelatihan pemanfaatan kelapa menjadi produk yang bisa mempunyai ekonomis yang tinggi. Beberapa hambatan yang terjadi masih dapat teratasi. Semua kegiatan dilakukan secara bertahap dan kontinu serta terkoordinir. Kegiatan ini secara nyata berdampak positif dengan berubahnya pola pikir dan cara pandang masyarakat terhadap kelapa yang sebelumnya hanya menjadi santan untuk memasak saja. Hasil dari kegiatan ini sangat dirasakan manfaatnya oleh masyarakat sehingga mereka mampu meningkatkan perekonomian mereka dengan memanfaatkan potensi kelapa yang ada di lingkungannya menjadi suatu produk yang dapat dijadikan sumber penghasilan guna meningkatkan taraf hidup mereka. Hasil dari kegiatan pengabdian yang dilaksanakan sejak sosialisasi, penyuluhan dan pelatihan adalah sebagai berikut:

1. Penyuluhan dan seminar tentang Perekonomian Masyarakat. Hasil yang dicapai : Masyarakat mengetahui pentingnya berwirausaha demi menunjang perekonomian.

2. Penyuluhan pembuatan minyak alami sari kelapa (VCO). Hasil yang dicapai : Masyarakat mengetahui manfaat buah kelapa selain di jadikan kopra dan dijual 
begitu saja, masyarakat mengetahui bahwa kita juga bisa membuat minyak alami yang kaya manfaat.

3. Pelatihan pengemasan produk. Hasil yang dicapai : Masyarakat mengetahui bagaimana cara pengemasan produk yang baik dan benar.

4. Pelatihan cara memasarkan produk. Hasil yang dicapai : Masyarakat mengetahui bagaimana cara memasarkan produknya dengan baik dan benar.

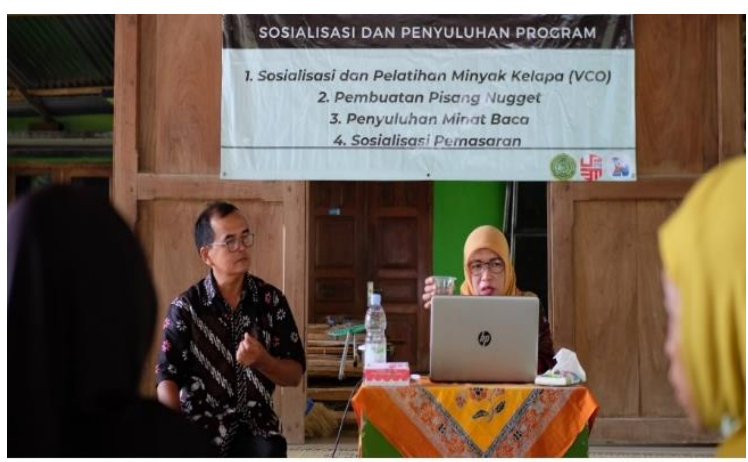

Gambar 1: Sosialisasi dan Penyuluhan

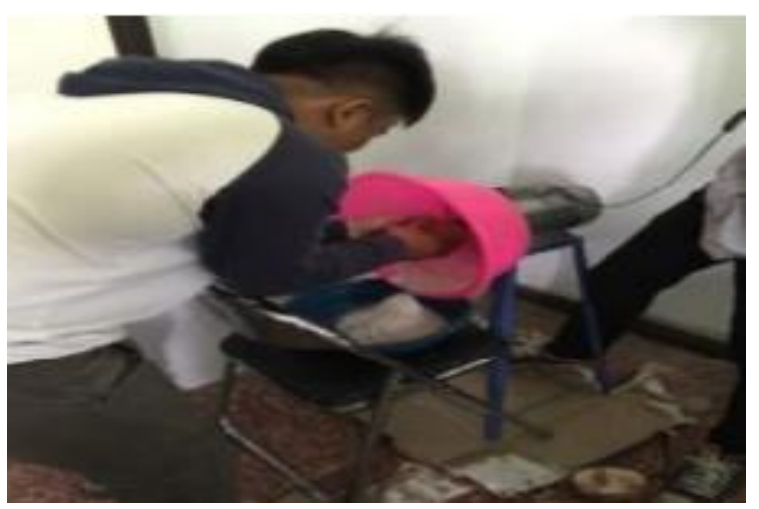

Gambar 2: Pemarutan kelapa

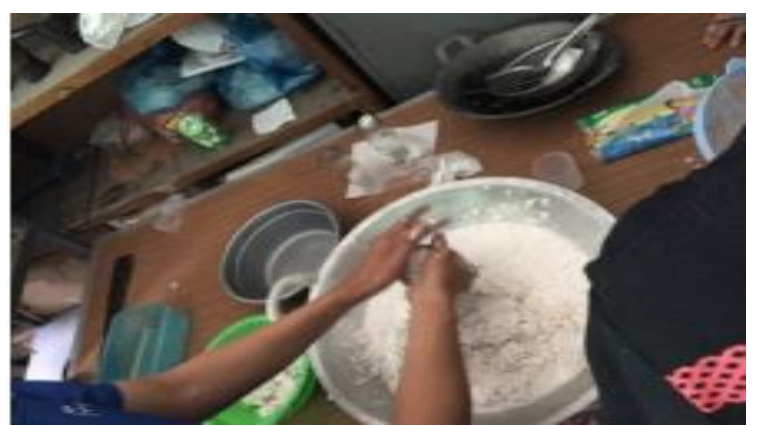

Gambar 3: Pemerasan Kelapa

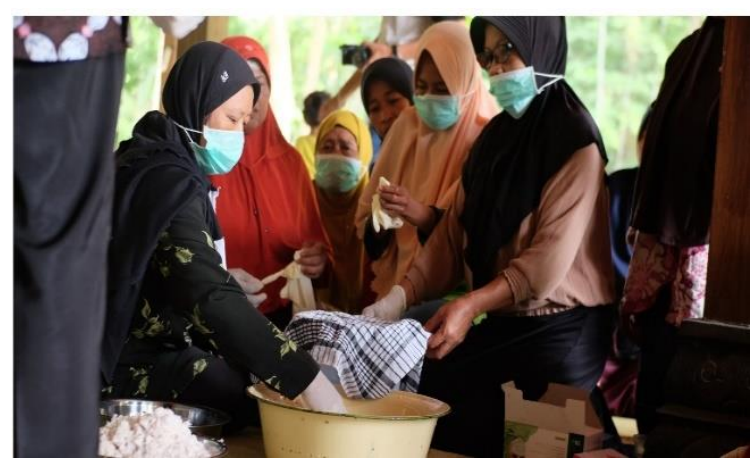

Gambar 4 :Penyaringan perasan kelapa

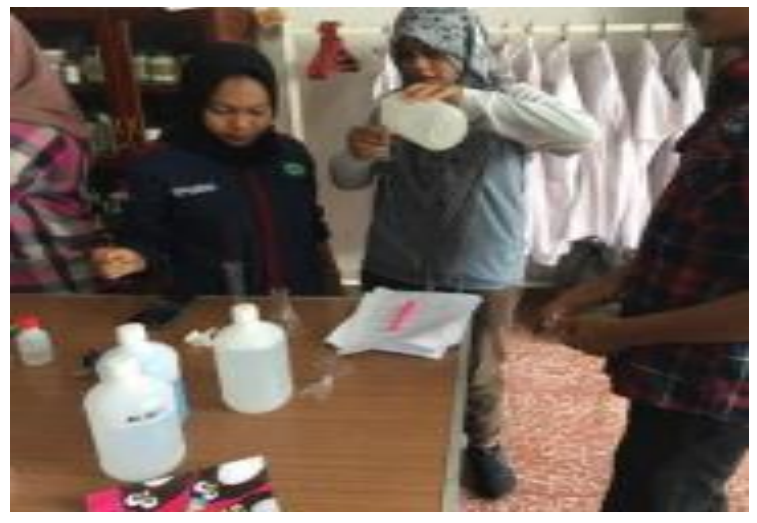

Gambar 5: Pengujian Kualitas VCO

\section{KESIMPULAN DAN SARAN}

Dari hasil kegiatan yang telah dilaksanakan, dapat diambil beberapa kesimpulan sebagai berikut:

1. Kegiatan pengabdian ini membawa dampak signifikan yaitu masyarakat memiliki pengetahuan tentang pemanfaatan buah kelapa sebagai bahan baku pembuatan VCO dan mengerti manfaat dari VCO sebagai produk makanan yang sehat,.

2. Kegiatan ini juga merubah pola pikir dan cara pandang masyarakat di Desa Sawahan Trimurti Srandakan Bantul dalam pemanfaatan kelapa untuk pembuatan VCO dan pemasarannya

Dari hasil kegiatan disarankan beberapa hal sebagai berikut:

1. Masyarakat harus merubah pola pikirnya dengan melihat kondisi di sekitarnya ada 
limbah yang bisa dimanfaatkan untuk meningkatkan taraf ekonomi mereka.

2. Masyarakat harus lebih antusias dan bertindak sebagai motivator yang membantu memecahkan masalah dan membantu membangun desa dan SDM Desa Sawahan

3. Pemerintah desa harus lebih giat lagi mengadakan sosialisasi, pelatihan dan pemanfaatan limbah kelapa yang banyak terbuang sia-sia dan tak berdaya ekonomi

4. Sedapat mungkin pemerintah desa mengundang pakar terkait pengelolaan limbah kelapa.

\section{UCAPAN TERIMAKASIH}

Terima kasih kami ucapkan kepada semua pihak terutama kepada Pemerintah Kabupaten Bantul terutama kepada Kepala Wilayah (Camat) Kec. Srandakan, pihak Pemerintah Desa (Kepala Desa Sawahan Trimurti), Mahasiswa KKN-PPM UMY dan masyarakat desa Sawahan Trimurti Srandakan Bantul serta pihak LP3M UMY atas dukungannya sehingga terlaksananya kegiatan ini dengan baik.

\section{DAFTAR PUSTAKA}

Alam Syah, Andi Nur. 2005. Virgin Coconut Oil Minyak Penakluk Aneka Penyakit. PT. Agro Media Pustaka, Depok.

Ahmad. 2006. Teknologi Pengolahan Minyak Kelapa. Jakarta: MAPI
Fitriani., Saputri., A. 2017. Pelatihan Pembuatan VCO sebagai Produk Makanan Sehat di Kota Alue IE Puteh Kecamatan Manyak Payed. Prosiding Seminar Nasional Penelitian dan pengabdian Pada Masyarakat. ISBN : 978-60261545-0-7.

Hidayat, sumangat dan Alamsyah. 2010. Produksi, pangsa pasar dan Diversifikasi produk olahan kelapa. Graha Media. Jakarta.

Palungkun, R. 2001. Aneka Produk Olahan Kelapa, (Cetakan kedelapan). Penebar Swadaya. Jakarta.

Raras., S.R., Pujiati., Utami., S. 2016. Pelatihan Pembuatan VCO Secara Fermentasi di Desa Belotan Bendo Magetan. Jurnal Terapan Abdimas. Vol 1 No.1.

Rindengan, Barlin dan Novarianto, Hengky. 2007. Minyak Kelapa Murni : Pembuatan dan Pemanfaatan. Penebar Swadaya, Depok.

Setiaji, B., dan Prayuga, S. 2006. Membuat VCO Berkualitas Tinggi. Jakarta : Penebar Swadaya.

Susanto, Tri. 2013. Perbandingan Mutu Minyak Kelapa yang diproses Melalui Pengasaman dan Pemanasan Sesuai SNI 29022011. Palembang: Jurnal Balai Riset dan Standardisasi Industri Widiayanti, R., A. 2015. Pemanfaatan Kelapa Menjadi VCO sebagai Antibiotik. Prosiding Seminar Nasional. 